\title{
A Vigília Lulalivre: sobre fazer casas e fazer política em um acampamento
}

João Vicente Marques Lagüéns ${ }^{1}$ Universidade Federal do Rio de Janeiro

Resumo: No presente trabalho busco explorar os sentidos, formas e implicações da construção de acampamentos de longa duração em processos de mobilização política, dando especial atenção às dinâmicas e relações cotidianas constituídas entre os participantes desses processos. O caso analisado é o movimento Lulalivre, no qual acompanho a dinâmica dos espaços constituídos pela militância na área vizinha à prisão do Presidente Lula, englobando palco para manifestações políticas e espaços mantidos por diferentes movimentos e coletivos na vizinhança, que servem como alojamento, espaço para refeições, estudo e trabalho.

Palavras-chave: antropologia da política; movimentos sociais; política; casa; domesticidade 


\title{
The Lulalivre Watch: building houses and playing politics form an encampment
}

\begin{abstract}
In this paper I seek to explore the meanings, forms and implications of a very singular social movement: the Vigília Lulalivre camp. The several spaces built by social movements and collectives in the area next to President Lula's prison housed political demonstrations, visits by personalities and events. They also provided a place for lodging, meals, meetings, conversations and gossip among activists. The daily life of these spaces reveals an intense "everyday politics" where domestic issues are mixed with the main national political disputes. Taking part in this environment and social networks formed there, made activists and their movements circulate nationally, reconfiguring their lives and their role in politics.
\end{abstract}

Keywords: political anthropology; social movements; politics; house; domesticity.

\section{La Vigilia Lulalivre: sobre hacer casas y hacer política en un campamento}

\begin{abstract}
Resumen: En este trabajo pretendo explorar los significados, formas e implicaciones de un movimiento social muy singular: el campamento de Vigília Lulalivre. Los diversos espacios construidos por movimientos y colectivos sociales en la zona próxima a la prisión del presidente Lula albergaron manifestaciones políticas, visitas de personalidades y eventos. También fueron lugar de alojamiento, comidas, reuniones, conversaciones y cotilleos entre los militantes. El día a día de estos espacios revela una intensa "política de lo cotidiano" en la cual las cuestiones domésticas se mezclan con las principales disputas políticas nacionales. La participación en este ambiente y en las redes sociales que allí se formaron, hizo que los activistas y sus movimientos circularan a nivel nacional, reconfigurando sus vidas y su papel en la política.
\end{abstract}

Palabras clave: antropología de la política; movimientos sociales; política; casa; domesticidad. 
prisão do Presidente Lula, em 7 de abril de 2018, teve enorme impacto.
Embora já fosse esperada, em função de interesses políticos e da condução
dada ao processo pela Operação Lava a Jato, a reação e mobilização contrária a ela surpreendeu até mesmo - ou principalmente - os mais convictos defensores do Presidente. Antes mesmo da chegada de Lula ao prédio da Polícia Federal onde ficaria preso em Curitiba, manifestantes, contrários e favoráveis, o aguardavam. No dia seguinte, centenas de barracas com pessoas dispostas a denunciar a arbitrariedade da prisão e demonstrar solidariedade ao ex-presidente ocupavam as ruas do bairro. Nos finais de semana seguintes, milhares de pessoas passaram por aquele acampamento que, mudando-se posteriormente para casas e espaços aluados na vizinhança manteve guarda e manifestações diárias nos 580 dias em que o Presidente esteve preso.

A ideia de ocupar a área próxima ao prédio da Polícia Federal era quase automática, afinal, ocupações e acampamentos são formas consagradas da luta política da esquerda e dos movimentos sociais que se juntavam ali. Acampamentos e ocupações duradouras são tecnologias de mobilização que, além da pressão e demonstração pública, servem para desenvolver, entre os participantes, laços de identidade e vínculos afetivos, através da descoberta de trajetórias e situações de vida comuns na convivência cotidiana. Especialmente nos movimentos de luta pela terra e por moradia, os acampamentos operam pela construção da unidade do movimento, servindo tanto à organização interna, ao promover formação e seleção dos seus membros, quanto conformando formas de organização e negociação específicas (como a "forma acampamento", analisada por Lygia Sigaud, 2000).

Aquele acampamento montado na porta da prisão de Lula era bem diferente dos modelos com que a esquerda estava acostumada. Ali havia tudo, menos trajetórias semelhantes e, para os objetivos políticos do movimento, ao contrário de reforçar a semelhança, era importante demarcar as diferenças. Pessoas e movimentos mais ou menos organizados afluíam com suas bandeiras, estilos, estéticas, corpos, modos de vestir, de mexer o corpo, marcando suas diferenças e sua presença em apoio a Lula... Muito mais do que homogeneidade, a paisagem marcava a pluralidade dos que vinham em defesa do Presidente.

É a partir dos pontos de vista abertos por esse acampamento, e em especial tentando me aproximar desses militantes mais aguerridos que, de fato, fizeram o acampamento permanecer até que o Presidente fosse libertado, que se estrutura o presente artigo. Na narrativa aqui apresenta dou especial atenção às casas, ou seja, aos espaços construídos pelos militantes em terrenos e casas alugadas na vizinhança, para que pudessem manter a Vigília Lulalivre - nome oficial do movimento. Estas casas foram muito mais do que o alojamento. Os militantes $d a$ vigília eram muitas vezes identificados através das suas casas - "ela é do Mariza" [o acampamento que ganhou o nome da esposa de Lula] ou "do Marielle" [a cozinha e espaço de convivência que levava o nome de Marielle Franco] - e essa associação das pessoas às suas casas era plena de sentido. A breve história de como foram montadas, de como as pessoas chegaram até elas e ali permaneceram, decantava vínculos com organizações, histórias de militância, posicionamentos políticos, características, estilos, afinidades e relações pessoais etc. Assim, ser de 
uma casa, resumia também, em certa medida, estilo, posicionamento político, afinidades etc. Dessa forma, as casas da vigília ganharam um sentido muito próximo àquele dado por Lévi-Strauss ao caracterizar as Sociedades de Casas: o de "pessoas morais" e tornaram-se, propriamente, personagens da Vigília. É claro que tratamos aqui de um universo muito diferente daquele das Sociedades de $\mathrm{Ca}$ sas, pois não se tratava de transmitir características, poder, demarcar identidades ou delimitar grupos que se perpetuam através das gerações. Tratava-se de um acampamento, necessariamente provisório, onde os arranjos de pessoas e recursos que compunham cada casa eram objeto de uma política do cotidiano, sempre em negociação nas conversas, comentários e fofocas que animavam a vida no acampamento. Dessa forma, o artigo percorre a trajetória de organização dessas casas, explorando as formas dessa política do cotidiano desenvolvida na Vigília e sua relação com a construção do movimento Lulalivre, a "grande política" nacional e as possibilidades de ação construídas pelos militantes que participam do acampamento.

\section{Ocupar espaços na vizinhança}

Cheguei a Curitiba 4 dias depois de Lula, no ônibus do PT de São Bernardo e já havia quase mil pessoas acampadas. O entorno das barracas do meu grupo dá ideia da composição desse acampamento. Havia, num raio de 50 meros, barracas da UJS, de uma organização feminista (jovens), um grupo do DCE da UFMG, a barraca do MST que armazenava as doações de comida para o acampamento, as barracas e uma 'central de comunicação' do PCO, barracas do sindicato dos metalúrgicos do $\mathrm{ABC}$, outra do sindicato dos químicos, umas tantas barracas de pessoas não identificadas com nenhuma essas unidades, além de um carrinho que vendia um sanduíche de pernil delicioso. A mesma diversidade se espalhava por 5 ou 6 quadras. Nos finais de semana e finais de tarde, as visitas faziam dobrar o número de pessoas que se integravam às conversas, discursos, cantoria, e dos gritos coletivos de "Bom dia", "boa tarde" e "boa noite Presidente Lula", que se tornaram marcas do acampamento.

A maior parte dos que estavam ali tinha trajetórias de militância e, exatamente por isso, reconheciam a novidade daquela ocupação. Para muitos, a prisão de Lula teve sentido disruptivo, como "a gota d'água", ou um verdadeiro terremoto em suas vidas, que exigia alguma ação. Para militantes mais experimentados, significava um momento em que estavam sendo postos em xeque, já que junto com a prisão de lula era sua própria trajetória militante que estava sendo criminalizada. Ao mesmo tempo, aquele cenário efervescente, a intensidade e novidade da mobilização provocada, sinalizavam uma retomada da capacidade de mobilização popular que não era vista a há anos, criando oportunidade de reaproximação e reinvenção de sua atividade militante. A coisa mais interessante para fazer ali era visitar os demais grupos acampados, conhecer aquelas pessoas, ouvir suas histórias, debater como organizar a esquerda e outras questões sem solução. Cozinhas (para lá de improvisadas, montadas pelos acampados) e a possibilidade de parar para tomar um cafezinho, uma água e descansar debaixo de uma barraca eram o suporte para chamar as pessoas, conversar, para provocar visitas e circulação.

Se a experiência de chegar ao acampamento Lulalivre era empolgante e parecia acenar para os participantes com a possibilidade de construir novas conexões e possibilidades de ação política, a precariedade do acampamento nas ruas era enorme e ficava evidente que aquele acampamento não poderia permanecer ali, 
daquela forma, por muito tempo. É claro que acampamentos e ocupações devem incomodar, perturbar a ordem; seu objetivo é justamente denunciar a anormalidade da situação contra a qual se insurge. Mas manter mil pessoas acampadas em 5 ou 6 ruas de um bairro pacato de subúrbio era insustentável. Havia, desde o primeiro momento, ordem judicial para desocupar as ruas. Uma comissão, formada por membros do PT, CUT, MST e MAB, assumira a representação institucional do movimento, que ganhara o nome de Vigília Lulalivre, e negociava as condições de permanência dos manifestantes. Assim, desde o início, uma das principais tarefas postas tanto para a coordenação como para os militantes era encontrar e negociar maneiras de permanecer ali. Além da constituição da coordenação, a construção de três espaços, foram cruciais para a permanência daquele acampamento.

O primeiro espaço montado foi uma cozinha, instalada na varanda da casa de uma das poucas famílias do bairro simpática ao movimento, que servia almoço e jantar para as centenas de pessoas que compunham o acampamento. A iniciativa partiu de militantes "independentes" que assumiram a função de 'tocar a cozinha', convenceram a dona da casa a alugar o espaço e a dirigentes de organizações a assumir custos de aluguel e da sua manutenção. Os alimentos vinham de doações, recebidas pela coordenação. Duas semanas depois da ocupação das ruas, a direção da Vigília conseguiu alugar um terreno para alojar os militantes, formando o acampamento Mariza Letícia. O Acampamento ficou pronto para o $1^{\circ}$ de Maio - dada especialmente importante para a CUT, quando foi realizado um grande ato pela libertação de Lula. "O Mariza" foi administrado pela coordenação da vigília por pouco menos de dois meses, passando depois a ser organizado e mantido pelos militantes que estavam lá. Pouco depois, quando já se esperava a ordem definitiva de desocupar as ruas, a coordenação conseguiu alugar um terreno exatamente em frente ao prédio da Polícia Federal, que tornou-se a sede da Vigília. Nesse espaço eram realizados todos os atos públicos da vigília. Ali ocorriam as saudações de bom dia, boa tarde e boa noite para o Presidente Lula, discursos, palestras, debates e uma série de "atividades culturais". Aquele era também o lugar onde chegavam diariamente visitantes anônimos e ilustres que vinham prestar solidariedade ao movimento e ao Presidente, e, principalmente, onde boa parte dos militantes passavam o dia.

Assim, em pouco menos de um mês, o movimento tinha construído as condições para permanecer naquela vizinhança que sempre lhe fora hostil. Muito significativamente, cada um dos espaços montados assumia a função típica de um cômodo de uma casa. A sede da vigília era a sala para receber os que chegam de fora, para as conversas e distrações que ajudam a passar o tempo, para conhecer pessoas ou apresentar amigos à família. A cozinha é o lugar onde se preparam os alimentos, mas também sãs conversas mais íntimas e das fofocas. Os quartos dão abrigo e podem ser compartilhados com os mais íntimos. Como em qualquer casa, nenhum desses espaços é plenamente público ou privado. Todos têm inscrições e significados com os quais se joga no cotidiano. Todos são políticos e politizáveis, cada um a seu modo.

\section{Permanecer}

A reação à prisão de Lula foi surpreendente. O número de pessoas e, o que chamava especialmente atenção, de figuras públicas que se manifestaram em sua defesa produziu um grande impacto. O fluxo de pessoas que visitavam o acampamento dava conta da importância dessa mobilização e animava os militantes que 
mantinham a vigília. Não tardou para que aquele acampamento se tornasse um polo para onde convergiam as manifestações de solidariedade e apoio a Lula. Milhares de cartas começaram a chegara à polícia federal ${ }^{2}$. As visitas dos advogados, que traziam mensagens de Lula, tornam-se eventos que pontuavam o cotidiano e eram transmitidos por redes sociais. As visitas de personalidades ao acampamento e, depois que foi admitida a visita de amigos na quinta-feira, animavam a agenda do acampamento e se desdobravam em discursos, palestras, rodas de conversa que também eram multiplicados através das redes sociais de pessoas e movimentos sociais participantes da vigília. Novas caravanas, organizadas principalmente por movimentos sociais, sindicatos e diretórios municipais do PT, que reforçavam as manifestações na porta da cadeia, chegava a cada semana. Além das caravanas, a vigília se mantinha com algo entorno de 300 a 500 pessoas (entre as que estabeleceram alojamento na vizinhança e a as que visitavam com frequência). Estava claro que movimento tinha conseguido significativo sucesso no seu objetivo político de denunciar as condições da condenação de Lula. Permanecia, no entanto, o desafio de manter o debate em pauta na sociedade, dar visibilidade aos argumentos de que a condenação era injusta e, em termos muito concretos, conseguir que Lula fosse solto, pudesse se candidatar à presidência e que ganhasse as eleições. Nesse processo, a Vigília teve um papel fundamental.

Num plano mais próximo, naquele acampamento3, além dos problemas "macro", da política nacional, outro conjunto de questões se colocava. O mais imediato, sem dúvida, era o das condições de vida, de como garantir a permanência da vigília e, também, como cada militante conseguia se manter ali. Isso passava, coletivamente, por arrecadar dinheiro para manter o aluguel dos espaços, o pagamento das contas e outras despesas e, também, pela grana curta que os militantes conseguiam com família, amigos e eventualmente com coletivos e vaquinhas virtuais que apoiavam esses "emissários" na frente de resistência. Tão importante quanto a solução desses problemas práticos era a construção de sentido para a sua permanência ali - problema que também se articulava simultaneamente no plano individual e coletivo. Este, obviamente, não era um problema "teórico", que dependesse da capacidade de enunciar objetivos ou pautas. E, embora muitas vezes as pessoas usassem expressões grandiloquentes, como "reinventar os sentidos da militância" ou "repensar a esquerda", a questão era muito mais concreta, imediata. Tratava-se da necessidade de dar sentido e consequência à ação cotidiana, conseguir tornar "produtiva" politicamente a permanência naquele acampamento, ampliando a visibilidade da denúncia à prisão de Lula, expandindo contatos, descobrindo aprendendo e se envolvendo com movimentos e companheiros da vigília. Dois elementos forram cruciais para que pudesse haver esse espaço de inventividade na militância da vigília: a) o enorme fluxo de apoios, eventos e pessoas que passava por ali; b) as necessidades concretas de organizar o espaço, alojar as pessoas, conviver com elas, e viabilizar formas de sobrevivência.

Nas falas de vários militantes, há um marco a partir do qual essa necessidade de construção de sentido e possibilidades de ação associadas à permanência na vigília se tornou mais evidente. Foi o dia 8 de julho de 20184, quando o desembargador Rogério Favreto do TRF-4 acatou um habeas corpus e mandou soltar

\footnotetext{
$2 \mathrm{O}$ Instituto Lula guarda um acervo de mais de 30 mil cartas recebidas pelo presidente no período em que esteve preso. 3 Uso, ao longo do texto, as expressões "vigília" e "acampamento" na tentativa de reproduzir uma discreta tensão, muito significativa, que existia em relação à denominação aquele lugar. Era comum que os visitantes chamassem o espaço de acampamento. A coordenação da vigília costumava corrigir: “vigília”. Os militantes que viviam na vigília, e se sabiam acampados, riam.

4 É interessante notar a estratégia política do movimento. A seleção brasileira de futebol tinha sido eliminada da Copa do Mundo no dia 6/7. A notícia da libertação de Lula, num domingo, tomou o noticiário, trazendo de volta o tema ao centro do debate político. Este evento, como muitos outros na vigília, faz parte de uma sequência de eventos que produziam, de
} 
Lula, mas o Juiz da primeira instância, Sergio Moro, foi capaz de extrapolar sua competência e conseguiu impedir o cumprimento da ordem judicial, até que o presidente do tribunal a revogasse. Nesse momento, as pessoas que viviam intensamente o acampamento perceberam duas coisas: 1) que aquele acampamento não seria tão provisório quanto se esperava inicialmente; 2) o seu iminente desamparo: "Se Lula sair o que acontece com a gente? O que acontece com tudo o que fizemos aqui?" (como resumiu Regiane, dona da casa onde estava instalada a cozinha da vigília).

Não é à toa que esse momento coincide com a época em que as casas da vigília começam a ganhar formas, ou a projetar uma aparência que sugere que seriam mais duráveis. $\mathrm{O}$ acampamento Mariza Letícia já era coordenado pelos próprios militantes que estavam morando ali e, a essa altura, se dedicavam a construir ou melhorar as instalações de cozinhas, banheiros e espaços comuns que atendiam às barracas. Os dois militantes que tocavam a cozinha - Tylle e Cabelo - alugaram um terreno mais próximo ao prédio da Polícia Federal, e começaram a construção do Espaço Marielle Franco, que além da cozinha, tem dois simpáticos galpões de madeira onde passou a funcionar um centro de formação do MST. Na lateral foi pintado um grande mural com rostos e frases dos principais líderes revolucionários - de Marx ao Papa Francisco. Os movimentos de mídia alternativa - Mídia Ninja, Brasil de Fato e Jornalistas Livres - alugaram uma casa bacana, chamada de Casa da Democracia, que, além de servir de alojamento para os mídia-ativistas e agregados, era um espaço aberto para quem frequentava a vigília e mantinha uma pilha de papéis para que os visitantes deixassem mensagens para o presidente Lula, que passaram a cobrir as paredes da sala - até o teto.

Com arranjos semelhantes, outros grupos fora estabelecendo suas casas. Foi montado um alojamento para militantes do MST. O Sindicato dos Metalúrgicos do ABC alugou uma casinha. Outros sindicatos paulistas alugaram apartamentos na vizinhança. Cada uma dessas casas acabou assumindo uma dinâmica própria, associada ao "estilo de vida" desenvolvido ali por seus "moradores". Elas são percebidas quase como se fossem pequenos movimentos ou organizações. Bem ao estilo levistraussiano, assumiram o sentido de "pessoas morais", combinavam diferentes mecanismos de incorporação de seus membros e, também, mecanismos para produzir sua reprodução, ou manutenção da sua existência para além da presença física das pessoas (cf. CARSTEN e HUGH-JONES, 1995). A questão, claramente, não era de identidade, mas sim relacionada à trajetória de cada uma dessas casas e dos encontros, alianças e relações estabelecidos por militantes e movimentos.

\section{Uma política do cotidiano}

Esse arranjo de casas espalhadas pela vizinhança que compunha a vigília se combinava a uma dinâmica bastante intensa de encontros, conversas, aproximações e afastamentos no cotidiano da vigília. Diariamente os participantes se reuniam na sede da vigília para os rituais de bom dia, boa tarde e boa noite ao presidente Lula. Durante a semana, esses encontros davam espaço a rituais específicos: nas sextas-feiras, o Boa Noite era chamado de "luzes para Lula", no domingo se transformava em ato ecumênico; a cada dia da semana caia a um dos movimentos sociais puxar as falas. Quando havia debates, palestras ou "atividades 
culturais" programados na sequência, era comum que os militantes se integrassem a essas atividades, se não, se espalhavam pelo terreno em rodas de conversa e violão.

Outras casas da casas da vigia - principalmente o quintal do Marielle - e mesmo as ruas do bairro, eram bons lugares para continuar as conversas que surgiam ali. Essas trocas eram, possivelmente, um dos principais espaços de aprendizado que motivavam os membros da vigília. Lembro da descrição de Cury, metalúrgico paranaense com 20 anos de atuação no sindicado, contando como a convivência com o pessoal do MST e a pedagogia prática da sua militância tinham o feito repensar seu próprio engajamento, ou como as narrativas das greves lideradas por Tucão, do sindicato dos químicos do $\mathrm{ABC}$, impedido a incorporação de empresas locais por grupos multinacionais visando manter os empregos, reuniam dezenas de pessoas. Não se tratava só de aprendizados, mas se desdobravam em ações concretas no próprio acampamento e na mobilização pela libertação de Lula, onde esses sindicatos e brigadas do MST passaram a programar ações conjuntas (o que não seria comum em outra situação). Foi se construindo, de fato, um ambiente de intensa troca entre os membros mais permanentes da vigília, especialmente entre os que permaneciam alojados em Curitiba e visitantes frequentes (como os dois sindicalistas mencionados ou eu mesmo). Vale notar que esses "visitantes frequentes" eram, de maneira geral, pessoas com grandes trajetórias na política e em movimentos sociais (e mesmo alguns políticos de maior destaque), com certa notoriedade e influência política, que conectavam a vigília a histórias e redes de militantes de suas organizações de origem. Isso, em vários momentos podia ser acionado solucionar uma questão prática, como uma lona nova para o acampamento ou a grana para pagar uma conta de energia, ou em ações mais próximas ao vocabulário político, como organização de um evento ou manifestação.

É importante notar que em uma ambiente como esse da vigília, as conversas, encontros e movimentos corriqueiros, como esse de sentar ou caminhar junto para conversar, são a forma de uma intensa política do cotidiano, através da qual se acompanha, regula e define uma comunidade moral. Em seus trabalhos, desenvolvidos em diferentes localidades da zona rural em Minas Gerais, John Comerford $(2003$; 2014) elabora diferentes formas de uma política do cotidiano, constituída a partir de uma prática marcante na sociabilidade nessas áreas: a atenta observação e os comentários feitos a respeito da circulação das pessoas entre as casas das vizinhanças. Num processo contínuo de observar, comentar e narrar os deslocamentos - e cientes que seus próprios deslocamentos e comentários serão também objeto de deslocamentos e comentários - os moradores dessas áreas, avaliam condutas, demarcam afinidades e distâncias, definem valores, negociando continuamente as formas e limites das comunidades morais que habitam. Em meu próprio trabalho (LAGÜÉNS, 2014), descrevi como, no período que antecedia as eleições, as conversas no quintal da casa de um importante político local exerciam o papel de dispositivo de controle das disputas políticas do município, permitindo ao dono da casa tomar conhecimento e intervir em um amplo campo de disputas, através daqueles que visitavam sua casa. Coerentemente com esses dois casos, pode-se observar que o conteúdo das conversas que se espalhavam pelas casas da Vigília Lulalivre eram igualmente objeto de um trabalho de atenção e glosa, através dos comentários e instrumentos de negociação de posicionamentos e tensões na política cotidiana da Vigília. Isso pode ser notado de maneira simplificada nos exemplos citados no parágrafo anterior. Os elogios de Cury à pedagogia do MST endereçavam a seus colegas metalúrgicos e do PT a defesa 
de que estes se aproximassem e apoiassem as ações do Movimento Sem Terra. Da mesma forma, a narrativa de Tucão sobre a inusitada coalizão de interesses entre trabalhadores e seus patões apelava à necessidade de construir alianças (ainda que improváveis) em função de uma conjuntura específica.

No cotidiano da Vigília, um papel complementar era desempenhado pelos visitantes mais ilustres. Tinha-se a impressão de que Curitiba nunca tinha recebido tantas personalidades, políticos, artistas e intelectuais, quanto naqueles meses que se sucederam à prisão de Lula. No acampamento isso gerava situações inusitadas, como ninguém saber muito bem a importância de uma figura muito importante - “quem é mesmo esse tal de Noam Chomsky?", me perguntaram os jornalistas que cobriam a visita - ou ninguém se interessar muito por um visitante ilustre: vi a Presidenta Dilma assumir a função de "fazer sala" para o cineasta Silvio Tendler, porque ninguém mais se prontificou a assumir a função. Além das situações engraçadas, do interesse e fascínio que algumas dessas visitas provocavam, produzindo momentos festivos e mudando o ritmo do acampamento, essas visitas chamavam atenção para a Vigília, recolocando, a cada semana, a questão da prisão do Presidente Lula, na pauta da imprensa e dos debates das diversas redes de apoiadores. Esses encontros projetavam as conexões dos militantes da vigília, faziam com que seus vídeos, "lives”, fotos e postagens de redes sociais circulassem por caminhos inéditos e, embora à primeira vista pareçam efêmeros e superficiais, a Vigília estava cheia de histórias de como tais contatos se transformaram conversas, ideias, visitas posteriores etc. A vigília era um lugar propício para fazer conexões 5 e, de fato, a extensão das redes e conexões daqueles militantes que estavam ali na vigília com outros grupos espalhados pelo país foi se tornando uma das suas principais tarefas. Em alguns casos poderiam render apoios, trocas ou ações com sentido prático imediato, mas seu principal sentido era o de estender uma rede de contatos, que servia como base de uma de articulação potencial e localizava aqueles militantes num universo político mais amplo, como será visto adiante.

\section{Os arranjos que mantinham as casas}

Também no que diz respeito à dimensão mais concreta das casas, as articulações construídas na vigília eram a base dos arranjos que as mantinham. Nenhuma das casas ou espaços mais importantes da vigília dependia exclusivamente de um movimento ou organização. Em todos os casos havia arranjos que envolviam organizações (como CUT, MST, sindicatos etc.) - normalmente mais de uma - e pessoas que não eram necessariamente ligadas a elas, mas que, na vigília, tinham assumido funções fundamentais para organização e manutenção desses espaços. Esse tipo de arranjo fazia com que a manutenção de cada espaço envolvesse uma negociação constante, entre organizadores, ocupantes e organizações. Tal dinâmica pode sugerir um ambiente cheio de tensões - o que efetivamente era muitas vezes o caso - mas é importante notar que esse conjunto de negociações formava uma política cotidiana e, em última instância, era através dele que eram trabalhadas as tensões e produziam-se os controles que permitiam manter a dinâmica da Vigília.

Se acompanharmos em detalhe a dinâmica interna de cada casa, vemos que em todas elas havia sempre questões que dizem respeito à vida dos militantes a

\footnotetext{
5 Certamente nenhum dos militantes que conheci foi para lá com a intenção de ampliar sua rede de contatos - e, por sinal, a maioria tinha bem pouco talento para isso - mas com a vivência cotidiana na vigília (e senso político, já que a maioria tinha significativa trajetória de militância)
} 
ser resolvidas: Chega mais uma pessoa, onde ela vai dormir? Dá para fazer um café fora de horário? Um ronca, o outro não cumpre o horário. Alguém precisa de um sabonete, ou de um casaco emprestado. Onde é que dá para tomar uma birita nesse bairro? E "fumar um"? Talvez seja justamente por juntar irremediavelmente pessoas e diferentes dimensões da vida, por produzir uma convivência onde não é possível separar totalmente nenhuma dessas dimensões, onde sentimentos, afetos, obrigações e a solução dos problemas imediatos da vida estão completamente intricados, que as casas fossem tão importantes para produzir e elaborar relações. $\mathrm{O}$ arranjo das casas do acampamento era bastante funcional para equacionar essas pequenas questões do cotidiano. Como cada casa era organizada por alguns militantes responsáveis por elas sem a interferência direta da coordenação da vigília, cabia a esses a solução dos pequenos problemas do cotidiano, deixando a coordenação da vigília relativamente resguardada dos pequenos atritos e insatisfações do cotidiano. Assim, tomadas em conjunto e na sua apresentação externa, as casas formavam um conjunto que operava de maneira coordenada para manutenção da Vigília e do movimento.

Se, no entanto, nos detivermos a observar as relações entre as diferentes casas da vigília sobressai um cenário onde o arranjo e manutenção de cada casa dependia de acordos e colaborações entre os diferentes movimentos e militantes. Vendo por outro ângulo, pode-se dizer que a manutenção dessas casas - e mesmo as próprias casas, sua forma e seus usos - espelhavam e eram parte das relações entre aqueles que as mantinham. Podemos tomar como exemplo o espaço Marielle Franco.

Nos primeiros dias de acampamento, as brigadas do MST montaram cozinhas em barracas, que distribuíam refeições para os seus militantes e para quem precisava. Pouco depois, um conjunto de pessoas se dispôs a assumir essa tarefa, a coordenação montou um sistema para receber doações e algumas pessoas do MST se incorporaram a esse grupo, que recebia reforços temporários das caravanas que chegavam. Um desses militantes, Tylle, do PT de São Paulo, assumiu a coordenação do trabalho da cozinha enquanto outro militante, Cabelo, além de ajudar na cozinha, era o responsável por conseguir, ora com a coordenação da vigília, ora com o MST, apoio e financiamento para os gastos da cozinha. Foi essa condição que permitiu que eles dois construíssem uma relação com um morador da vizinhança que aceitou alugar para eles um terreno onde seria construído o espaço Marielle Franco, abrigando além da cozinha, salas usadas como um centro de formação do MST e alojamento para os dois e o painel com "líderes revolucionários".

Rapidamente esse espaço se tornou um lugar central para a vigília. Além das refeições, e das jornadas de formação para as caravanas do MST, era o lugar para onde iam muitos dos militantes quando cansavam de permanecer na sede da vigília. Servia especialmente para conversas ais longas e um pouco mais reservadas, aproveitado a desculpa de tomar um café. Todos os que visitam a Vigília - ilustres ou não - são convidados a visitar o Espaço Marielle e admirar o mural dos líderes revolucionários. Tylle aproveitava os personagens para puxar assunto com quem estivesse por ali e hoje mantém uma rede de contatos com "revolucionários" de todo o mundo. O Espaço Marielle - da mesma forma que as demais casas da vigília - dava grande visibilidade a seus coordenadores, posicionando-os em lugar de potencial destaque nas redes de ralação que se juntavam na vigília. Estar nessa posição de destaque permitia e essas pessoas construir um amplo leque de relações, que, em parte, era o que lhes permitia criar e manter ações na própria vigília (já que essas ajudas eram acionadas em momentos necessários), mas também 
como um recurso em potencial, um “capital político”. Não é difícil imaginar que além dos aspectos positivos, esses lugares de destaque eram objeto de disputa.

A construção do espaço Marielle foi garantida, basicamente pelo Movimento Sem Terra, que se comprometeu inclusive a pagar o aluguel e as contas, mas a responsabilidade pelo espaço (inclusive o contrato de aluguel) eram do Tylle. Isso significa que, a cada mês, ele precisa negociar com os coordenadores do MST o repasse do dinheiro. O mesmo acontece com as doações de alimento, que chegam através da coordenação da vigília. Assim, a cada início de mês, para pagar as contas, ou a cada três dias, para receber os alimentos para preparar as refeições, os coordenadores do espaço têm de negociar com a coordenação da vigília e do MST. Nenhum desses apoios é incondicional. Há sempre a possibilidade de uma demora no repasse ou a resposta de que "dessa vez não vai dar", como de fato eventualmente acontece, exigindo buscar apoio em outro lugar. Para as direções dos movimentos, essa é uma forma de manter algum controle os coordenadores do Espaço. Assim, militantes independentes e movimentos mais institucionalizados mantém um equilíbrio instável que está sempre em negociação. Não se trata apenas de controle de uns sobre os outros, mas da produção de um espaço que depende da interação - e que existe graças as potencialidades dessa interação.

Desde o início, o MST se posicionou como um movimento fundamental para estruturação da Vigília - especialmente por manter o maior contingente constante de pessoas entre os movimentos sociais que a compunham, através de caravanas que, semanalmente, traziam grupos de diversos assentamentos. Durante a maior parte do tempo, o movimento optou por não ter uma "casa do MST", o que foi uma escolha coerente com sua pedagogia (paulofreireana) da militância. Os assentados do MST que vinham nas caravanas se hospedavam na Casa Lula (o alojamento da creche) junto com as demais caravanas e alguns militantes "permanentes" da vigília; tinham cursos e atividades de formação no Espaço Marielle; participavam das atividades na sede da vigília - isso sem contar as "fugidas", escapando do movimento coordenado das caravanas. Assim, "o pessoal do MST" estava constantemente interagindo com os demais membros da vigília. Para os que tinham menor experiência de militância essa era uma oportunidade de aprendizado e troca com gente de maior experiência política. Para o Movimento, além de dar visibilidade à sua presença, permitia explorar ao máximo as possibilidades de cooperação e construção de conexões abertas pela Vigília, participando intensamente da sua "política cotidiana" com múltiplos agentes.

Assim, a série de situações destacadas aqui mostra alguns elementos significativos em relação a estas casas da Vigília Lulalivre. O primeiro desses elementos é que nenhuma dessas casas existe, ganha sentido, ou se constituiu ou se manteve isoladamente, por ação de uma organização ou grupo de militantes. Todas estiveram sempre em relação umas com as outras, construindo seus usos e significados nas relações e contrastes estabelecidos entre umas e outras. Um lugar permitia o recolhimento ou convivência mais íntima graças à existência de outros espaços que permitiam o encontro e convivências mais públicas. O Acampamento Mariza Letícia era visto como lugar dos militantes mais libertários ou indisciplinados, justamente porque essa avaliação era feita em contraste com o alojamento da Creche, com regras mais rígidas. Da mesma forma, todas as casas tinham sido construídas e se mantinham pela combinação de esforços de diversas pessoas e movimentos da vigília, e esses arranjos de cooperação sofriam modificações ao longo do tempo. A construção de relações, a negociação de acordos ou, de maneira mais ampla, a política cotidiana da Vigília estava sempre presente na organização e manutenção das casas. Essa dinâmica gerava uma relação de complementaridade 
entre as casas. Militantes podiam se alojar ora num espaço, ora em outro, tipos de função, como preparar refeições ou receber visitantes podiam ser realizadas em diferentes espaços dependendo da ocasião ou do estado das relações entre os membros da vigília. Uma imagem bastante sugestiva para caracterizar essa pluralidade de arranjos entre as casa é a de configuração de casas formulada por Lois Marcelin (1999) caracterizando aos arranjos de moradia e organização das famílias negras no Recôncavo Baiano. O autor mostra que a combinação dos sentidos de família, parentesco e casa (onde a ideia de família se aproxima a de aqueles que moram juntos e parentes são pensados como aqueles com quem se pode contar) está relacionada a uma dinâmica de vida onde os membros dessas famílias moram, se hospedam, buscam ajuda e constroem soluções para a sobrevivência numa rede ampliada de casas de parentes espalhadas por diversas localidades. Em função disso, as próprias casas que compõe essas configurações de casas devem ser entendidas não como dado, mas como parte desse processo de construção da vida dessas pessoas. Dinâmica muito semelhante às casas do Lulalivre, que mais do que lugares estabelecidos eram parte de processos sempre em negociação através dos quais se mantinha a vitalidade do Movimento.

\section{Depois da derrota}

Um breve olhar para a dinâmica da Vigília e as soluções encontradas pelos seus membros após a derrota do candidato do PT nas eleições presidenciais de 2018 reforça a importância da construção de relações - e do papel das casas para isso - como parte central da inventividade e das potencialidades de criação presentes naquele movimento. Depois das eleições, encarando a derrota, o lema público foi o "ninguém solta a mão de ninguém", mas ali estava claro que vários arranjos precisavam ser refeitos e as pessoas precisavam dar rumo a suas vidas. Não necessariamente deixar a vigília, mas dar novo sentido e soluções práticas à vida. O sentimento era de desamparo, nunca tinham feito tanto sentido as perguntas sobre "o que fazer, depois de tudo o que fizemos aqui?", ou, como alguém resumiu à época: "O que você tem depois de ter chutado a sua vida para o alto e ir passar 6 meses gritando bom dia, boa tarde e boa noite para o barbudo?" As soluções, encontradas pelos militantes, foram justamente de usar aquilo que havia sido construído ali para dar continuidade às suas vias.

Edna, que coordenava o Acampamento Mariza Letícia resolveu deixar, junto com outros, o acampamento, pegar uma Kombi e criar uma "caravana Lulalivre" itinerante pelo Brasil. Pegou a rede de contatos das pessoas que tinham passado pelo acampamento e passou a acioná-las, marcar atividades militantes com cada uma delas e ir visitando essas pessoas, fazendo manifestações junto com elas, fazendo a campanha Lulalivre pelo Brasil. O Cabelo, do Espaço Marielle, resolveu que tinha que escrever um livro sobre a vigília. Ele tinha conhecido uma professora de literatura de Recife, que escreve cordéis e propôs a ele transformar o livro em cordel. Ele foi pra Recife montar um comitê Lulalivre e os dois seguiram trabalhando juntos no livro de cordel. Outro personagem, o Batista do Megafone, que anda sempre com um capacete com uma placa Lulalivre em cima e está há mais de um ano na vigília, começou a produzir e vender camisetas numa da campanha Lulalivre numa barraquinha na vigília.

Em certo sentido, isso não é radicalmente diferente da solução dada por políticos profissionais. Lindberg Farias perdeu a eleição para senador e criou um canal de Youtube. Manuela D'Ávila está escrevendo livros. Todos continuam 
construindo estratégias que os permite continuar a fazer política a partir das relações que são capazes de mobilizar. Lindberg, por exemplo, era uma figura bastante presente na Vigília e construiu uma significativa rede de relações a partir daí. Sua atuação política e a capilaridade da rede de relações que ele é capaz de mobilizar se espalhou para muito além do seu estado de origem. Guardadas as devidas proporções, universo de inter-relações, e de contatos e trocas efetivas dos militantes de base do Lulalivre, como Cabelo e Edna, também se estenderam enormemente, ganharam escala nacional. Através dessas relações o acampamento Lulalivre se espalhou pelo Brasil, construindo uma rede potente de acolhimento e criatividade, reformulando a configuração de casas (cf. MARCELIN, 1999) desenhada na Vigília.

Fim

As "casas"da vigília Lulalivre são mecanismos que deram àquelas pessoas forma de atuar na política. Essas casa possibilitaram que novos atores entrassem a tivessem protagonismo na política. Casas marcam, produzem interações, servem de referência e marcam as relações.

Dentro dessas casas e a partir delas, através dessa multiplicidade de conversas, encontros, visitas, amizades e brigas, falas públicas e fofocas constituem o tecido do que é fazer política. E, nisso, se aproximam a "grande política", dos políticos profissionais que atuam nacionalmente, e a "pequena política" de militantes que, todos os dias, gritam bom dia, boa tarde e boa noite para o presidente Lula.

Recebido em 30 de setembro de 2020.

Aceito em 20 de novembro de 2020.

\section{Referências}

CARSTEN, Jannet; HUGH-JONES, Stephen. Introduction. In: CARSTEN., J.; HUGH-JONES, S. (eds.), About the House: Lévi-Strauss and Beyond. Cambridge: Cambridge University Press, 1995. pp. 1-46.

COMERFORD, John Cunha. Como uma família: Sociabilidade, territórios de parentesco e sindicalismo rural. Rio de Janeiro: Relume-Dumará, 2003.

COMERFORD, John Cunha. Vigiar e narrar: sobre formas de observação, narração e julgamento de movimentações. Revista de Antropologia, 57 (2), 2014.

LAGÜÉNS, João Vicente Marques. Casa e Política: amizade, alianças e interesses. Tese de Doutorado em Antropologia Social, Universidade Federal do Rio de Janeiro, 2014. 
MARCELIN, Louis Herns. A linguagem da casa entre os negros no Recôncavo Baiano. Mana, 5 (2): 31-60, 1999.

PALMEIRA, Moacir. Política, facções e voto. In: PALMEIRA, Moacir, HEREDIA, Beatriz. Política Ambígua. Rio de Janeiro: Relume-Dumará, 2010.

SIGAUD, Lygia. A forma acampamento: notas a partir da versão pernambucana. Novos Estudos, 58: 73-92, 2000. 